\title{
Extruded snacks with the addition of different fish meals
}

\author{
Elenice Souza dos Reis GOES ${ }^{1}$, Maria Luiza Rodrigues de SOUZA ${ }^{2 \star}$, Daniel Abreu Vasconcelos CAMPELO², \\ Grazyella Massako YOSHIDA ${ }^{4}$, Tadeu Orlandi XAVIER ${ }^{5}$, Lorena Batista de MOURA ${ }^{5}$, \\ Antonio Roberto Giriboni MONTEIRO 6
}

\begin{abstract}
Tilapia, salmon, tuna and sardine meals were prepared to develop and analyze extruded snacks with residue meal from fish processing. Residue meals were included in five types of corn snacks: control ( $0 \%$ fish meal) and four with $9 \%$ tilapia, salmon, tuna and sardine meals. Although moisture, lipids and carbohydrates rates did not differ among the snacks, protein rates increased with the increment of fish meal, reaching $11.85 \%$ in the tuna snack. Tuna and sardine snacks had the highest iron levels. The most abundant fatty acids were linoleic, oleic, palmitic, linolenic and stearic acids, with sardine, salmon and tuna snacks presenting the highest values of n-3 series fatty acids. Greater luminosity rate was reported for salmon snack, followed by tilapia, tuna and sardine snacks. The highest sensory acceptance index was verified in tilapia (78.07\%) and salmon (72.40\%). A $9 \%$ addition of residue meals of tilapia, salmon and tuna improved the nutritional value of the snacks.
\end{abstract}

Keywords: fishery technology; corn snack; residue reuse.

Practical Application: Snacks with fish meal have higher nutritional rates.

\section{Introduction}

Fish have relevant nutritional value due to their high protein and minerals level (calcium, phosphor and iron). Moreover, lipid contents in saltwater fish are one of the greatest sources of fatty acids from the omega-3 family (n-3) (Godoy et al., 2010; Lima et al., 2012). In spite of Brazil's considerable water potential and increase in fish production throughout the country, the consumption of fish per capita is $14.5 \mathrm{~kg} /$ inhabitant/year (Brasil, 2014), lower than the world average consumption (19.2 kg/inhabitant/year) (Food and Agriculture Organization of the United Nations, 2014). To make matter worse, children are a minority among consumers (Godoy et al., 2010).

One approach to increase consumption is by boosting offer and by diversifying fish derived products (Haj-Isa \& Carvalho, 2011). In fact, the production of convenient, ready-to-eat food, such as the snacks, may be an alternative (Maluf et al., 2010). Growth in fish consumption and its derivatives in human nutrition might contribute towards the improvement of consumers' health (Maluf et al., 2010), besides enhancing adequate fish-residue management, job creation and expansion of sustainable development (Godoy et al., 2010).

Fish processing industries may generate residues, such as heads, viscera, fins, tails, backbones, flakes and meat remains, with amounts close to $50 \%$ of the original feedstock (Arruda et al., 2006;
Feltes et al., 2010; Nunes et al., 2013). The processed residues are used in fish meal production for animal nutrition, since they have nearly $70 \%$ of protein (Arruda et al., 2006). However, due to their high biological value, fish residues have been studied for possible use in human consumption (Godoy et al., 2013) by including them in other processed foods, such as snacks (Justen et al., 2011).

Snacks are extruded products, or rather, they undergo a process in which raw material is forced by a matrix, under specific conditions of mixture, heating, pressure and friction, leading towards starch gelatinization and protein denaturation (Thakur \& Saxena, 2000). Since snacks are appreciated by people of all ages, mainly children and teenagers, there is an appeal for the nutritional improvement of this product (Ferreira, 2006) and an opportunity for the inclusion of fish meals in snacks. Justen et al. (2011) developed snacks with flavored tilapia carcass meal and observed that the addition of up to $12 \%$ increased the contents of proteins, lipids, minerals, without affecting the product's sensory characteristics.

Current analysis develops and characterizes extruded snacks with the inclusion of meals produced from residues from tilapia, tuna, salmon and sardine processing.

${ }^{1}$ Programa de Pós-Graduação em Ciência de Alimentos, Centro de Ciências Agrárias, Universidade Estadual de Maringá - UEM, Maringá, PR, Brazil

${ }^{2}$ Departamento de Zootecnia, Centro de Ciências Agrárias, Universidade Estadual de Maringá - UEM, Maringá, PR, Brazil

${ }^{3}$ Instituto de Estudos Costeiros, Universidade Federal do Pará - UFPA, Bragança, PA, Brazil

${ }^{4}$ Programa de Pós-Graduação em Genética e Melhoramento Animal, Faculdade de Ciências Agrárias e Veterinária, Universidade Estadual Paulista "Júlio Mesquita Filho" UNESP, Jaboticabal, SP, Brazil

${ }^{5}$ Programa de Pós-Graduação em Zootecnia, Centro de Ciências Agrárias, Universidade Estadual de Maringá - UEM, Maringá, PR, Brazil

${ }^{6}$ Departamento de Engenharia de Alimentos, Centro de Tecnologia, Universidade Estadual de Maringá - UEM, Maringá, PR, Brazil

*Corresponding author: mlrsouza@uem.br 


\section{Materials and methods}

Meal production was carried out in the Laboratory of Fishery Technology of the Iguatemi Experimental Farm, of the Universidade Estadual de Maringá. Finless tilapia carcasses (Oreochromis niloticus), tuna torsos (Thunnus spp.) without fins (with bones, skin and muscles, from non-standard fish classification), salmon finless carcasses (Salmo salar) and sardine tails (Sardinella brasiliensis) were used to produce the meals. All raw materials came from residues of fishery processing companies in the region of Maringá PR Brazil and Itajaí SC Brazil.

The raw material was washed in chlorine water, weighed, and stored separately in $20 \mathrm{~L}$-industrial pressure cookers containing enough water to cover the feedstock. Further, $0.5 \mathrm{mg} / \mathrm{kg}$ of antioxidant, $0.5 \%$ sodium bicarbonate $(\mathrm{NaHCO} 3)$ and $0.5 \mathrm{mg} / \mathrm{kg}$ of peracetic acid $15 \%$ were used. The residue was cooked on an industrial stove for sixty minutes. After this period, the water was discarded and residue was pressed in a hydraulic press. The cake was milled in an electric meat grinder and the resulting dough dehydrated in a drying kiln by forced ventilation for 24 hours, at $60{ }^{\circ} \mathrm{C}$. After dehydration, the dough was milled in a Willey mill and fish meals were produced for the extruded snacks. Fish meals were conditioned in plastic bags and stored at ambient temperature until the manufacture of the snacks.

The snacks were produced in the Laboratory of Grain Technology of the Food Engineering Course of the Universidade Estadual Maringá, Maringá PR Brazil, on 11/30/2012. Five types of snacks were prepared: control (without fish meal) and four types of snacks with the addition of $9 \%$ tilapia meal, $9 \%$ tuna meal, $9 \%$ salmon meal and 9\% sardine meal, totaling five treatments, with four replications for each product. The level 9\% was based on previous assays by Justen et al. (2011).

The preparation of the snacks required corn grits as the main ingredient, to which were added $9 \%$ of meals and $2 \%$ of water, mixed manually. The extrusion was conducted in a $50 \mathrm{~kg} / \mathrm{h}$ Inbramaq extruder (IB-50 Model). After extrusion, the snacks were weighed and seasoned with $2 \%$ of salt, $2 \%$ of ready-made seasoning and $8 \%$ of soybean oil, in a rotary dryer. Snacks were stored at room temperature in plastic bags for further assessment of their percentage, mineral and fatty acids composition, luminosity, and microbiological and sensory analyses.

Processing conditions, hygiene and handling of snacks were evaluated by a microbiological analysis for coliforms at $35^{\circ} \mathrm{C}$ and $45^{\circ} \mathrm{C}$, coagulase positive Staphylococcus by direct technique and Salmonella spp (Brasil, 2003a) for all snacks.

Moisture, protein, lipid and ash rates for snack control and snacks with meal addition were carried out in triplicate, following methodology by AOAC (Associations of Official Analytical Chemists, 2005). Carbohydrate content was determined by the difference between other components (Brasil, 2003b), whereas total calorie rates were obtained by the sum of protein, lipid and carbohydrate averages multiplied by 4,9 and 4 , respectively (Souci et al., 2000).

Calcium, phosphorus and iron rates were determined in triplicate for snacks with meals. Phosphorus was calculated according to methodology by Silva \& Queiroz (2002), whereas the samples were digested in acid medium and quantification conducted by flame atomic absorption spectrophotometry to determine calcium and iron rates (Zhou et al., 1998).

Fatty acids profile was established for control snack and for snacks with meal addition and fatty acids were quantified following methodology by Associations of Official Analytical Chemists (2005).

The color of snacks was determined with a Minolta colorimeter (model $\left.{ }^{\circ} \mathrm{CR}-10\right)$ at an angle of $90^{\circ}$, at room temperature, in triplicate, for every sample of snack with meal addition. Scale $L^{*}, a^{*}, b^{*}$ from CIELAB system, developed by Hunter (1975), was employed, where $L^{*}$ defines luminosity $\left(L^{*}=0\right.$ black and $\mathrm{L}^{*}=100$ white), $\mathrm{a}^{\star}$ (red-green component) and $\mathrm{b}^{*}$ (yellow-blue component).

Sensory analysis was performed at the Laboratory of Sensory Analysis of the Food Engineering Course of UEM, with 100 untrained tasters randomly chosen among employees and students of the Universidade Estadual de Maringá, Maringá PR Brazil. The methods of sensory analysis were approved by the Committee for Ethics in Research on Human Beings (COPEP) of the Universidade Estadual de Maringá, Maringá PR Brazil (CAAE: 14219213.1.0000.0104). Snack samples (snack with addition of tilapia meal, snacks with salmon meal, tuna meal and sardine meal) were offered to the judges under white light in separate booths. The four samples were placed in disposable plastic cups, and identified with three random numbers each.

A 9-point structured hedonic scale was applied to evaluate the snacks' characteristic profile (appearance, aroma, flavor, crunchiness and overall impression), set between minimum and maximum: 1 (I disliked it very much) and 9 (I liked it very much) (Dutcosky, 2007). The samples were also submitted to the purchase intention test, using a 5-point hedonic scale with extremes 1 (I certainly would not buy it) and 5 (I certainly would buy it). Together with the sensory analysis form, a cup of water was offered to remove aftertaste.

The Expression 1 was used to evaluate the products' Acceptability Index (AI):

$A I \%=\frac{\text { average grade obtained for product }}{9} \times 100$

Data obtained in different analyses were submitted to variance analysis (ANOVA) at 5\% significance and Tukey's test were applied with Statistical Analysis System (SAS, SAS Inst. Inc. Cary, NC, USA) when significant differences occurred $(\mathrm{P}<0.05)$.

\section{Results and discussion}

\subsection{Microbiological analysis}

According to Resolution 12 of RDC published on 01/12/2001, snacks are included in the item "salty and sweet products, extruded or not, fried, roasted or compacted, including cracklings and similar products". The above resolution establishes a maximum of $5 \times 10 \mathrm{CFU} / \mathrm{g}$ of coliforms at $45^{\circ} \mathrm{C}$ and absence of Salmonella spp in $25 \mathrm{~g}$ of sample (Brasil, 2001). Table 1 shows that the microbiological profile of snacks reveals that 
the product was processed in hygienic conditions, suggested by Brazilian Legislation.

\subsection{Centesimal composition}

The centesimal composition of extruded snacks demonstrated that moisture and lipid contents did not present any difference $(\mathrm{P}>0.05)$ (Table 2). Protein, mineral matter, carbohydrates and calorie were different for the different snacks $(\mathrm{P}<0.05)$.

Snack control had $6.82 \%$ protein, whereas the addition of fish meal increased protein rates. Tuna snack had the highest protein rates (11.85\%) among the snacks with fish meal, followed by the sardine and tilapia snacks (respectively with $10.21 \%$ and $9.80 \%)$, whilst the salmon snack had the lowest protein rates (9.21\%). Different protein rates in the snacks may be due to the prime matter in the manufacture of meals. In fact, tuna meal was produced from the truck, with more meat and less bones, when compared to the carcasses used for the other types of meals.

Proteins in fish muscles have a high biological value with a balanced amino acid composition, especially the limiting ones in proteins of vegetable origin, such as methionine and cysteine (Neves et al., 2004). Therefore, protein increments in snacks with fish meal are an important protein source of high biological value. In snacks with $9 \%$ smoked tilapia carcass meal, Justen et al. (2011) reported $10.28 \%$ protein and $3.97 \%$ minerals.

Crude protein rates in current study are similar to those registered by Soares et al. (2011) when adding rice and bean meals to corn snacks, with rates varying between 7.18 and $10 \%$, but higher than $4.8 \%$ by Ferreira (2006) in snacks with $87.7 \%$ corn and $12.3 \%$ wheat bran. As the corn-only snacks have low nutritional value, the addition of fish meal may be an alternative to enrich these products mainly in protein and mineral contents.

Tilapia snacks featured the highest rates in mineral matter (5.84\%) whilst the lowest ones occurred in tuna snacks (2.79\%).
Lowest contents in mineral matter and highest protein contents in snacks with tuna meal may be due to greater muscle inclusion and consequently fewer bones, with low ash levels. Salmon and sardine snacks had similar ash rates ( 4.30 and $4.21 \%$, respectively).

Tilapia snacks had the lowest carbohydrate rates $(70.85 \%)$ when compared to others. No difference $(\mathrm{P}>0.05)$ was reported when snacks with fish meals were compared to control snack, by Dunnet's test. Tuna snack had an average higher caloric rate $(394.95 \mathrm{kcal} / 100 \mathrm{~g})$ when compared to the tilapia snack $(380.52 \mathrm{kcal} / 100 \mathrm{~g})$. When snacks with fish meal were compared to control by Dunnet's test, only the tuna snack was different $(\mathrm{P}<0.05)$ from the control snack, with $394.95 \mathrm{kcal} / 100 \mathrm{~g}$. Extruded snacks may be considered an energy product due to their considerable carbohydrate contents (Carvalho et al., 2012). Further, caloric value increases since the snacks are flavored with fat or oil, as a fixer of seasonings and salt (Capriles et al., 2009). Since samples of commercial corn snacks presented caloric rates $467.2 \pm 105.2 \mathrm{kcal} / 100 \mathrm{~g}$, lipids rates $14.3 \pm 8.0 \%$, protein rates $6.8 \pm 1.8 \%$ and carbohydrate rates $77.7 \pm 17.0 \%$ (Capriles et al., 2007), the snacks with fish meals improved the product's nutritional value when compared to commercial ones.

\subsection{Calcium, phosphorus and iron composition}

Calcium, phosphorus and iron contents in snacks had significant differences $(\mathrm{P}<0.05)$ among the different fish meals (Table 3). Different snacks made from different meals had similar mineral composition, except the tuna meal with the lowest $(\mathrm{P}<0.05)$ calcium and phosphorus rates when compared to the others. Snacks with tuna and sardine showed higher levels of iron when compared to those in tilapia and salmon snacks.

Snacks with $9 \%$ of smoked tilapia carcass meals presented rates of $0.554 \mathrm{~g} / 100 \mathrm{~g}, 0.344 \mathrm{~g} / 100 \mathrm{~g}$ and $9.08 \mathrm{mg} / 100 \mathrm{~g}$ respectively for calcium, phosphorus and iron (Justen et al., 2011). Calcium and phosphorus rates were similar to those reported in current

Table 1. Microbiological analysis of extruded snacks with the addition of fish meal.

\begin{tabular}{|c|c|c|c|c|c|}
\hline & \multirow{2}{*}{ Snack Control } & \multicolumn{4}{|c|}{ Snack with the addition of fish meal } \\
\hline & & Tilapia & Salmon & Tuna & Sardine \\
\hline Coliforms at $35^{\circ} \mathrm{C}(\mathrm{NMP} / \mathrm{g})$ & 3.6 & 3.6 & 3.6 & $<3$ & 3.6 \\
\hline Coliforms at $45^{\circ} \mathrm{C}(\mathrm{NMP} / \mathrm{g})$ & $<3$ & $<3$ & $<3$ & $<3$ & $<3$ \\
\hline Salmonella spp & Absent in $25 \mathrm{~g}$ & Absent in $25 \mathrm{~g}$ & Absent in $25 \mathrm{~g}$ & Absent in $25 \mathrm{~g}$ & Absent in $25 \mathrm{~g}$ \\
\hline Coagulase positive Staphylococcus (CFU/g) & $<10^{2}$ & $<10^{2}$ & $<10^{2}$ & $<10^{2}$ & $<10^{2}$ \\
\hline
\end{tabular}

CFU/g - Colony Forming Units/gram; MPN/g - Most Probable Number/gram.

Table 2. Centesimal composition and caloric value of extruded snacks with fish meal.

\begin{tabular}{|c|c|c|c|c|c|}
\hline \multirow{2}{*}{ Parameters (\%) } & \multirow{2}{*}{ Snack Control } & \multicolumn{4}{|c|}{ Snacks with the addition of fish meal } \\
\hline & & Tilapia & Salmon & Tuna & Sardine \\
\hline Moisture $^{\mathrm{ns}}$ & $6.93 \pm 0.35$ & $7.07 \pm 0.98$ & $6.74 \pm 0.55$ & $6.64 \pm 0.51$ & $6.20 \pm 0.28$ \\
\hline Crude protein & $6.82 \pm 0.19$ & $9.80 \pm 0.49 b c$ & $9.21 \pm 0.17 \mathrm{c}$ & $11.85 \pm 0.21 \mathrm{a}$ & $10.2 \pm 0.21 b$ \\
\hline Lipids ${ }^{\text {ns }}$ & $6.40 \pm 0.29$ & $6.44 \pm 0.38$ & $6.39 \pm 0.63$ & $6.54 \pm 0.80$ & $5.93 \pm 1.12$ \\
\hline Mineral matter & $5.18 \pm 0.31$ & $5.84 \pm 0.47 \mathrm{a}$ & $4.30 \pm 0.31 b$ & $2.79 \pm 0.57 c$ & $4.21 \pm 0.27 b$ \\
\hline Carbohydrates & $74.6 \pm 0.08$ & $70.85 \pm 1.19 \mathrm{~b}$ & $73.36 \pm 0.32 \mathrm{a}$ & $72.18 \pm 1.38 \mathrm{ab}$ & $73.46 \pm 0.97 \mathrm{a}$ \\
\hline Caloric Value (kcal/100g) & $383.57 \pm 1.97$ & $380.52 \pm 1.16 \mathrm{~b}$ & $387.81 \pm 4.84 \mathrm{ab}$ & $394.9 \pm 5.56 \mathrm{a}$ & $388.04 \pm 6.54 \mathrm{ab}$ \\
\hline
\end{tabular}

${ }^{\text {ns }}$ not significant $(\mathrm{P}>0.05)$. Means on the same line followed by distinct letters are different by Tukey's test $(\mathrm{P}<0.05)$. Rates in Mean \pm Standard deviation. 
study for snacks with different meals. When compared to standard rates of extruded corn grits snacks registered by Justen et al. (2011) (Table 3), the inclusion of fish meals proved to be effective in enriching corn snacks with calcium, phosphorus and iron. For instance, the iron content in snacks with fish meal was higher than that in pork $(0.77 \mathrm{mg} / 100 \mathrm{~g})$, chicken thighs $(0.99 \mathrm{mg} / 100 \mathrm{~g})$ and bovine loin (1.58 mg/100 g) (Sarcinelli et al., 2007).

\subsection{Composition of fatty acids}

In current analysis, twenty-six fatty acids could be identified in snacks (Table 4). The most abundant were linoleic (18:2n-6 c), oleic (18:1n-9 c), palmitic (16:00), linolenic (18:3n-3) and stearic acid (18:00).

Snacks with sardine, salmon and tuna meals presented high rates of $n-3$ series fatty acids, given in Table 4 . This is due to the

Table 3. Calcium, iron and phosphorus contents in snacks with fish meal.

\begin{tabular}{|c|c|c|c|c|c|}
\hline \multirow{2}{*}{ Parameters } & \multirow{2}{*}{ Snack control ${ }^{1}$} & \multicolumn{4}{|c|}{ Snacks with meal addition } \\
\hline & & Tilapia & Salmon & Tuna & Sardine \\
\hline Calcium (\%) & 0.097 & $0.63 \pm 0.05 \mathrm{a}$ & $0.52 \pm 0.02 \mathrm{a}$ & $0.12 \pm 0.01 \mathrm{~b}$ & $0.47 \pm 0.04 \mathrm{a}$ \\
\hline Phosphorus (\%) & 0.026 & $0.46 \pm 0.04 \mathrm{a}$ & $0.39 \pm 0.02 \mathrm{a}$ & $0.20 \pm 0.01 \mathrm{~b}$ & $0.37 \pm 0.02 \mathrm{a}$ \\
\hline Iron $(\mathrm{mg} / 100 \mathrm{~g})$ & 5.99 & $14.84 \pm 0.45 b$ & $15.61 \pm 0.54 b$ & $20.94 \pm 0.54 \mathrm{a}$ & $18.41 \pm 0.84 \mathrm{a}$ \\
\hline
\end{tabular}

${ }^{1}$ Rates obtained by Justen et al. (2011) in extruded corn grits snacks. Means on the same line followed by distinct letters differ by Tukey’s test (P < 0.05$)$. Rates given in Mean \pm Standard deviation.

Table 4. Fatty acids composition (g/kg) of extruded snacks with fish meal.



Abbreviations: ND - not detected; SFA - sum of saturated fatty acids; MUFA - sum of monounsaturated fatty acids; PUFA - sum of polyunsaturated fatty acids; n- 6 and n-3 - sum of fatty acids of n- 6 and n-3 series, respectively; PUFA/SFA - ratio between the sum of polyunsaturated and saturated acids; and n-6/n-3 - ratio between the sum of n- 6 and n- 3 series acids. 
fact that saltwater fish have a higher content of fatty acids since their nutrition chain consists of unicellular algae with nearly $20 \%$ of their dry weight constituted by lipids, of which $50 \%$ are polyunsaturated fatty acids, mainly from omega-3 series (Martino, 2003). In contrast, fresh water fish, such as the tilapia, are naturally composed of a high concentration of omega- 6 fatty acids. The high concentration of n-6 fatty acids in all snacks is due to the fact that, to incorporate seasonings, soybean oil was used as a vehicle. Vegetable oils produced from sunflower, safflower, maize, soybean and cotton seeds, provide high contents of fatty acids of the n- 6 series, mainly linoleic acid (18:2n-6) (Novello et al., 2008), a fatty acid found in high quantities in all snacks. This fact increased the ratio between fatty acids n- 6 and n-3 in snacks, varying between 6.10 and 11.70 .

Contrastingly, all snacks provided rates above 2.57 for the PUFA/SFA ratio. Ratios exceeding 0.40 are recommended since they prevent cardiovascular diseases (Wood et al., 2004).

\subsection{Luminosity}

Significant differences were observed $(\mathrm{P}<0.05)$ for components $\mathrm{L}^{*}, \mathrm{a}^{*}$ and $\mathrm{b}^{*}$ in the color of snacks with fish meal (Table 5). Greater luminosity $\left(\mathrm{L}^{*}\right)$ was found in snack with salmon meal, followed by tilapia, tuna and sardine snack, perhaps due to meal coloration. In fact, salmon and tilapia meals have lighter colors when compared to tuna and sardine meals. The component $b^{*}$, which indicates the yellow-blue color, displayed the highest rate for salmon snack, whilst sardine snack was the darkest $(\mathrm{P}<0.05)$. Low rates of chroma $\mathrm{a}^{*}$ in all snacks demonstrated that the red shade was very subtle.

The gradual increase from 0 to $12 \%$ of flavored tilapia meal addition in extruded snacks caused a linear decrease in luminosity: $12 \%$ level showed $L^{*}$ of 73.63 and $0 \%$ level showed $\mathrm{L}^{\star}$ equal to 79.12 (Justen et al., 2011). Therefore, the inclusion of fish meal in corn snacks diminished intensity of luminosity and yellow coloration. The rise of protein content contributed towards a decrease in luminosity and to higher rates in $a^{*}$ chroma in snacks made of cassava flour enriched with casein (Lustosa et al., 2010).

\subsection{Sensorial analysis}

Profile analyses of different extruded snacks (Table 6) registered significant differences $(\mathrm{P}<0.05)$ for all attributes. The judges assigned higher grades $(\mathrm{P}<0.05)$ to tilapia and salmon snacks when compared to tuna and sardine snacks with regard to their color. However, between the latter two, the sardine snack was preferred. The highest grades $(\mathrm{P}<0.05)$ were awarded to the aroma in tilapia and salmon snacks, according to judges. Tilapia, salmon and sardine snacks did not differ from each other $(\mathrm{P}>0.05)$ when crunchiness was assessed, with superior grades $(\mathrm{P}<0.05)$ for the tuna snack. The judges attributed higher grades $(\mathrm{P}<0.05)$ to tilapia snack for the criteria flavor and overall impression, followed by salmon snack (Table 6).

In general, tilapia snacks received grades between 6 and 7 (slightly liked or moderately liked) for all tested criteria. Snacks with salmon meal obtained similar grades as those for the tilapia, varying between 5 (neither liked/nor disliked) and 7 (slightly liked), but grade 7 was given only for color. The lowest grades were attributed to snacks with tuna meal, 3 (moderately disliked) to maximum grade 5 (neither liked/nor disliked), with the highest given to crunchiness. Varying between 4 (slightly liked) and 6 (moderately liked), snacks with sardine meal did not obtain high grades, according to the judges.

The acceptance index, which measures products' acceptability percentage, was higher $(\mathrm{P}<0.05)$ for snacks with tilapia and salmon meal, respectively with $78.07 \%$ and $72.40 \%$, followed by sardine meals (57.19\%), and lastly, tuna meals $(50.42 \%)$ (Table 6). Results were lower to those by Maluf et al. (2010) who reported $97 \%$ acceptability for fresh pasta dough with pacu fillets

Table 5. Color of extruded snacks with fish meal.

\begin{tabular}{cccrcr}
\hline & \multirow{2}{*}{ Control snack $^{1}$} & \multicolumn{4}{c}{ Snacks with fish meal } \\
\cline { 2 - 6 } & & Tilapia & Salmon & Tuna & Sardine \\
\hline $\mathrm{L}^{*}$ & 79.12 & $70.24 \pm 1.55 \mathrm{~b}$ & $71.81 \pm 0.82 \mathrm{a}$ & $63.38 \pm 1.16 \mathrm{c}$ & $61.53 \pm 1.29 \mathrm{~d}$ \\
$\mathrm{a}^{*}$ & 1.8 & $-10.8 \pm 0.16 \mathrm{~d}$ & $-10.44 \pm 0.13 \mathrm{c}$ & $-5.89 \pm 0.19 \mathrm{a}$ & $-8.58 \pm 0.21 \mathrm{~b}$ \\
$\mathrm{~b}^{*}$ & 28.8 & $31.04 \pm 0.88 \mathrm{~b}$ & $33.61 \pm 0.84 \mathrm{a}$ & $32.04 \pm 0.91 \mathrm{~b}$ & $27.09 \pm 0.96 \mathrm{c}$ \\
\hline
\end{tabular}

${ }^{1}$ Rates by Justen et al. (2011) in extruded corn grits snacks. Means on the same line followed by distinct letters differ by Tukey's test $(\mathrm{P}<0.05)$. Rates in Mean \pm Standard deviation.

Table 6. Characteristic profile of extruded snacks with fish meals ${ }^{1}$.

\begin{tabular}{ccccc}
\hline \multirow{2}{*}{ Parameter } & \multicolumn{4}{c}{ Snack with fish meal } \\
\cline { 2 - 5 } & Tilapia & Salmon & Tuna & Sardine \\
\hline Color $^{2}$ & $7.68 \pm 1.12 \mathrm{a}$ & $7.81 \pm 1.20 \mathrm{a}$ & $3.98 \pm 1.64 \mathrm{c}$ & $4.69 \pm 1.88 \mathrm{~b}$ \\
Aroma $^{2}$ & $6.59 \pm 1.61 \mathrm{a}$ & $6.13 \pm 1.63 \mathrm{a}$ & $4.88 \pm 2.07 \mathrm{~b}$ & $4.66 \pm 2.00 \mathrm{~b}$ \\
Crunchiness $^{2}$ & $6.61 \pm 1.71 \mathrm{a}$ & $6.59 \pm 1.82 \mathrm{a}$ & $5.47 \pm 2.31 \mathrm{~b}$ & $6.42 \pm 1.89 \mathrm{a}$ \\
Flavor $^{2}$ & $7.02 \pm 1.58 \mathrm{a}$ & $5.59 \pm 2.02 \mathrm{~b}$ & $4.12 \pm 2.23 \mathrm{c}$ & $4.78 \pm 2.05 \mathrm{c}$ \\
Overall impression $^{2}$ & $7.18 \pm 1.25 \mathrm{a}$ & $6.41 \pm 1.66 \mathrm{~b}$ & $4.33 \pm 2.07 \mathrm{c}$ & $4.91 \pm 1.97 \mathrm{c}$ \\
${\text { Acceptance índex }(\%)^{2}}_{\text {Purchase intention }^{2,3}}^{78.07 \pm 12.50 \mathrm{a}}$ & $72.40 \pm 13.57 \mathrm{a}$ & $50.42 \pm 18.45 \mathrm{c}$ & $57.19 \pm 17.56 \mathrm{~b}$ \\
\hline
\end{tabular}

${ }^{1}$ Hedonic scale between 1 and $9 .{ }^{2}$ Means on the same line followed by distinct letters differ by Tukey's test $(\mathrm{P}<0.05) .{ }^{3}$ Hedonic scale between 1 and 5 . Rates in Mean \pm Standard deviation. 
(Piaractus mesopotamicus) peeled off, gutted, smoked, crushed and included at $30.6 \%$ level of pasta dough.

Justen et al. (2011) reported that the addition of up to $12 \%$ of flavored tilapia meal did not affect sensory parameters (aroma, flavor, appearance, texture, color and overall acceptance) of extruded corn snacks, obtaining grades between 6.92 and 8.15 for all attributes. In current study, tilapia and salmon snacks were preferred instead of tuna and sardine snacks, possibly, because the last two presented an enhanced fish flavor.

In the purchase intention test, all snacks presented significant differences. The highest grade was for snack with tilapia meal inclusion, followed by the snacks with salmon, sardine and tuna meal, respectively (Table 6).

Since an acceptance index above $70 \%$ indicates that a product will be well accepted on the market (Dutcosky, 2007), it may be perceived that the addition of tilapia and salmon meals is viable to increase the protein contents of snacks, with satisfactory sensory acceptance. Tuna and sardine meals in snacks, although improving nutritional value, were not well accepted with regard to purchase intention test and to sensory parameters, as the acceptance index (50.42\% for tuna and $57.19 \%$ for sardine) demonstrated.

\section{Conclusion}

A $9 \%$ addition of residue meal of tilapia, salmon and tuna was effective in improving the nutritional value of extruded corn snacks, with tilapia and salmon meals in snacks presenting greater sensory acceptance when compared to tuna and sardine snacks.

\section{Acknowledgements}

The authors would like to thank the company Gomes da Costa (Itajaí SC Brazil) for providing raw material to produce the meals, to $\mathrm{CNPq}$ and the Araucária Foundation for the scholarships.

\section{References}

Arruda, L. F., Borghesi, R., Brum, A., D’Arce, M. R., \& Oetterer, M. (2006). Nutritional aspects of Nile tilapia (Oreochromis niloticus) silage. Ciência e Tecnologia de Alimentos, 26(4), 749-756. http:// dx.doi.org/10.1590/S0101-20612006000400006.

Associations of Official Analytical Chemists - AOAC. (2005). Official methods of analyses of the association of analytical chemists (18th ed.). Washington, DC: AOAC.

Brasil. Ministério da Agricultura, Pecuária e Abastecimento. (2003a August 26). Oficializa os métodos analíticos oficiais para análises microbiológicas para controle de produtos de origem animal e água (Instrução Normativa n ${ }^{\circ} 62$, de 26 de agosto de 2003). Diário Oficial [da] República Federativa do Brasil.

Brasil. Ministério da Saúde. (2003b December 23). Aprova o regulamento técnico sobre rotulagem nutricional de alimentos embalados (RDC no 360, de 23 de dezembro de 2003). Diário Oficial [da] República Federativa do Brasil.

Brasil. Ministério da Pesca e Aquicultura. (2014). Ministro Eduardo Lopes lançou 11 a Semana do Peixe em Brasília. Brasília, DF: MPA.
Retrieved from http://www.mpa.gov.br/index.php/ultimas-noticias/423ministro-eduardo-lopes-lanca-11-semana-do-peixe-em-brasilia.

Brasil. Ministério da Saúde. (2001, January 2). Regulamento técnico sobre padrões microbiológicos para alimentos $\left(\mathrm{RDC} \mathrm{n}^{\circ} 12\right.$, de 02 de janeiro de 2001). Diário Oficial [da] República Federativa do Brasil.

Capriles, V. D., Soares, R. A. M., \& Arêas, J. A. G. (2007). Development and assessment of acceptability and nutritional properties of a light snack. Ciência e Tecnologia de Alimentos, 27(3), 562-566. http:// dx.doi.org/10.1590/S0101-20612007000300021.

Capriles, V. D., Soares, R. A. M., Pinto e Silva, M. E. M., Arêas, J. A. G., \& Arêas, J. A. G. (2009). Effect of fructans-based fat replacer on chemical composition, starch digestibility and sensory acceptability of corn snacks. International Journal of Food Science \& Technology, 44(10), 1895-1901. http://dx.doi.org/10.1111/j.1365-2621.2009.01915.x.

Carvalho, A. V., Bassinello, P. Z., Mattietto, R. A., Carvalho, R., Rios, A., $\&$ Seccadio, L. L. (2012). Processamento e caracterização de snack extrudado a partir de farinhas de quirera de arroz e de bandinha de feijão. Brazilian Journal of Food Technology, 15(1), 72-83. http:// dx.doi.org/10.1590/S1981-67232012000100008.

Dutcosky, S. D. (2007). Análise sensorial de alimentos (2th ed., Coleção Exatas, 239 p.). Curitiba: Champagnat.

Feltes, M. M. C., Oliveira, J. V., Treichel, H., Block, J., Oliveira, D., \& Ninow, J. L. (2010). Assessment of process parameters on the production of diglycerides rich in omega-3 fatty acids through the enzymatic glycerolysis of fish oil. European Food Research and Technology, 231(5), 701-710. http://dx.doi.org/10.1007/s00217-010-1325-4.

Ferreira, R. E. (2006). Avaliação de parâmetros do processo de extrusão e do teor de farelo de trigo adicionado em características de "snacks" expandidos de milho (Doctoral Thesis). Universidade Estadual de Campinas, Campinas. $162 \mathrm{f}$.

Food and Agriculture Organization of the United Nations - FAO. (2014). The state of the world fisheries and aquaculture 2014 (223 p.). Rome: FAO.

Godoy, L. C., Franco, M. L. R. S., Franco, N. P., Silva, A. F., Assis, M. F., Souza, N. E., Matsushita, M., \& Visentainer, J. V. (2010). Análise sensorial de caldos e canjas elaborados com farinha de carcaças de peixe defumadas: aplicação na merenda escolar. Ciência $e$ Tecnologia de Alimentos, 30, 86-89. http://dx.doi.org/10.1590/ S0101-20612010000500014.

Godoy, L. C., Franco, M. L. R. S., Souza, N. E., Stevanato, F. B., \& Visentainer, J. V. (2013). Development, preservation, and chemical and fatty acid profiles of Nile tilapia carcass meal for human feeding. Journal of Food Processing and Preservation, 37(2), 93-99. http:// dx.doi.org/10.1111/j.1745-4549.2011.00624.x.

Haj-Isa, N. M. A., \& Carvalho, E. S. (2011). Desenvolvimento de biscoitos, tipo salgado, enriquecidos pela adição de merluza. Ciência e Tecnologia de Alimentos, 31(2), 313-318. http://dx.doi.org/10.1590/ S0101-20612011000200006.

Hunter, R. S. (1975). The measurement of appearance (348 p.). New York: John Wiley \& Sons.

Justen, A. P., Franco, M. L. R. S., Monteiro, A. R. G., Mikcha, J. M. G., Gasparino, E., \& Delbem, A. B. (2011). Inclusión de harina de pescado en snacks. Infopesca Internacional, 47, 35-38.

Lima, M. M., Mujica, P. I. C., \& Lima, A. M. (2012). Caracterização química e avaliação do rendimento em filés de caranha (Piaractus mesopotamicus). Brazilian Journal of Food Technology, 15(spe), 41-46. http://dx.doi.org/10.1590/S1981-67232012005000031.

Lustosa, B. H. B., Leonel, M., \& Mischan, M. M. (2010). Parâmetros de extrusão na produção de snacks de farinha de mandioca enriquecidos com caseína. Semina: Ciências Agrárias, 31, 129-146. 
Maluf, M. L. F., Weirich, C. E., Dallagnol, J. M., Simões, M. R., Feiden, A., \& Boscolo, W. R. (2010). Elaboração de massa fresca de macarrão enriquecida com pescado defumado. Revista do Instituto Adolfo Lutz, 69, 84-90.

Martino, R. C. (2003). Exigências e cuidados da adição de lipídeos em rações para peixes e a sua importância para o homem. Parte 2. Revista Panorama Aqüicultura, 13, 58-60.

Neves, R. A. M., Mira, N. V. M., \& Marquez, U. M. L. (2004). Caracterização de hidrolisados enzimáticos de pescado. Ciência e Tecnologia de Alimentos, 24(1), 101-108. http://dx.doi.org/10.1590/ S0101-20612004000100019.

Novello, D., Franceschini, P., \& Quintiliano, D. A. (2008). A importância dos ácidos graxos w-3 e w-6 para a prevenção de doenças e na saúde humana. Revista Salus, 2, 77-87.

Nunes, R. M., Viana, A. M., Son, C. B. M. W., Brum, L. R., Oliveira, L. P., \& Costa, H. G. (2013). Aproveitamento de resíduos de pescado na região dos lagos: uma questão ambiental. Revista Saúde, Corpo, Ambiente e Cuidado, 1, 58-70.

Sarcinelli, M. F., Venturini, K. S., \& Silva, L. C. (2007). Características da carne suína (Boletim Técnico, 7 p.). Espírito Santo: UFES.
Silva, D. J., \& Queiroz, A. C. (2002). Análise de alimentos: métodos químicos e biológicos (235 p.). Viçosa: Editora UFV.

Soares, M. S. Jr., Santos, T. P. B., Pereira, G. F., Minafra, C. S., Caliari, M., \& Silva, F. A. (2011). Desenvolvimento de salgadinhos extrusados a partir de fragmentos de arroz e de feijão. Semina: Ciencias Agrárias, 32, 191-200.

Souci, S. W., Fachman, H., \& Kraut, E. (2000). Foods composition and nutrition tables (1182 p.). Stuttgart: Medpharm GmbH Scientific Publishers.

Thakur, S., \& Saxena, D.C. (2000). Formulation of extruded snack food (gum based cereal-pulse blend): optimization of ingredients levels using response surface methodology. Lebensmittel-Wissenschaft undTechnologie, 33, 354-361. http://dx.doi.org/10.1006/fstl.2000.0668.

Wood, J. D., Richardson, R. I., Nute, G. R., Fisher, A. V., Campo, M. M., Kasapidou, E., Sheard, P. R., \& Enser, M. (2004). Effects of fatty acids on meat quality: a review. Meat Science, 66(1), 21-32. http://dx.doi. org/10.1016/S0309-1740(03)00022-6. PMid:22063928.

Zhou, H. Y., Cheung, R. Y. H., Chan, K. M., \& Wong, M. H. (1998). Metal concentrations in sediments and tilapia collected from inland waters of Hong Kong. Water Research, 32(11), 3331-3340. http:// dx.doi.org/10.1016/S0043-1354(98)00115-8. 